\title{
Urban growth modeling using cellular automata model and AHP (case study: Qazvin city)
}

\author{
Nahid Falah ${ }^{1} \cdot$ Alireza Karimi $^{2} \cdot$ Ali Tavakoli Harandi $^{3}$
}

Received: 29 August 2019 / Accepted: 23 October 2019 / Published online: 16 November 2019

(c) The Author(s) 2019

\begin{abstract}
Irregular growth in the surrounding lands is one of the most important issues for the city managers and programmers at various levels. Whereas nowadays study the process of land use changes to urban use plays the main role in long time decisions and programs, predicting the process of city growth and its modeling in future with precise methods for management and urban expansion control will be necessary more than other times. One of urban growth modeling is cellular automata model. This model has been used widely in urban studies because of its dynamic nature, ability of Integration with other models, ability to modify the model and required data availability. In this article, to maximize the efficiency of the cellular automata model and its constraints, the integration of the AHP automated cell model and cellular automata model have been used; and its accuracy has been evaluated. This article has been practical because its related principles has been collected in a documentary manner and has been used to analyses the issue in comparative and quantitative methods. Initially, the unplanned growth of Qazvin city has been investigated by Holdern and Shannon model. Then main parameters including distance from roads, land prices, distance from faults, distance from the rivers, soil gender, slope, permission to build land, topography, landscape, view to gardens and forest park as parameters involved in the development of Qazvin city are considered. The input data used in this research are Landsat tm and DEM images of the city of Qazvin in 1996 and 2016. Also, to evaluate the correctness of the model responses, the map of the developed regions in 2016 and the Kappa coefficient have been used. The Kappa coefficient is $92.3 \%$, which is considered significant and appropriate and gave the fact that the Kappa number is acceptable. The Qazvin simulation was made in 2026. The results show that the proposed integrated model is suitable for studying urban growth.
\end{abstract}

Keywords Urban simulation · Shannon's and Holdern entropy model's · Urban growth-cellular automata · Analytic hierarchy process

Alireza Karimi

alireza.kariimii1992@gmail.com

Nahid Falah

nahid.falah.hcu@gmail.com

Ali Tavakoli Harandi

Alitavakoli202@gmail.com

1 Faculty of Architecture and Urbanism, Imam Khomeini International University, Qazvin, Iran

2 Building and Environment Research Laboratory, Iran University of Science and Technology, Tehran, Iran

3 Faculty of Architecture and Urban Planning, Islamic Azad University Isfahan Branch, Tehran, Iran

\section{Introduction}

Worldwide urban and regional development has undergone many changes over the past 50 years (CHU and Tang 2005). Continued urban growth and development has put major challenges on the structure and functioning of subsystems in the city and the region (Natale et al. 2015) Due to the responsibility of policy makers in the area of regional planning (Greenhalgh and Gudgeon 2004), it is necessary to pay attention to the development process in the management of complex systems (Barredo et al. 2003) at the city and district level. As a result, exploring urban development is important. Based on the view of different people, various tools and methods for simulating spatial and urban dynamics, such as cellular automation simulation models, fractal model, linear regression or logistic, 
Table 1 Key driving factors to urban growth extracted from existing CA models (Wahyudi and Liu 2013)

\begin{tabular}{|c|c|c|c|c|}
\hline Geomorphology & Connectivity & & Facilities & Environment \\
\hline $\begin{array}{l}\text { Slope } \\
\text { Elevation } \\
\text { Hill-shade }\end{array}$ & $\begin{array}{l}\text { Highway } \\
\text { Tollgate/ramp } \\
\text { Road } \\
\text { Waterways } \\
\text { Railways } \\
\text { Intersection }\end{array}$ & & $\begin{array}{l}\text { Station } \\
\text { Airport } \\
\text { Major towns } \\
\text { Shopping centre } \\
\text { Business centre } \\
\text { Industrial } \\
\text { Existing developed areas } \\
\text { School } \\
\text { Health facilities } \\
\text { Thematic } \\
\text { Recreational }\end{array}$ & $\begin{array}{l}\text { Greenery } \\
\text { Other }\end{array}$ \\
\hline Government & Constraints & Demography & Land & Economy \\
\hline $\begin{array}{l}\text { Zoning } \\
\text { Institutional factor }\end{array}$ & $\begin{array}{l}\text { Water bodies } \\
\text { National parks, forest } \\
\text { Wetlands } \\
\text { Protected areas }\end{array}$ & $\begin{array}{l}\text { population size } \\
\text { Annual growth rate } \\
\text { Population density } \\
\text { Migration }\end{array}$ & $\begin{array}{l}\text { Land suitability } \\
\text { Land availability } \\
\text { Land genetic }\end{array}$ & $\begin{array}{l}\text { Gross domestic products (GDP) } \\
\text { Land value } \\
\text { Economic trends }\end{array}$ \\
\hline
\end{tabular}

technique multivariate evaluation (Barreira-González et al. 2015), dynamic model, baseline model (Qiu-Hao and Yun-Long 2006), conventional models have problems with analysis, due to the lack of dynamic information, because they cannot meet the needs for spatial-temporal simulation (He et al. 2015). Using of dynamic models which include spatial-temporal information are useful for simulating complex geographic systems (He et al. 2015). Among the models mentioned, the model of AHP cellular automation is due to its specific nature and benefits such as simplicity (because at the beginning, the parameter values are automatically obtained by complementary models efficiency due to the modification and development of several models) independent variables (Yang et al. 2013; Barreira-González et al. 2015) have become more widely used over the past two decades. Von Neumann and Stanislaw Ulam (Junfeng 2003) presented the concept of automated cells, in the field of computer science, for the first time in 1940, then Conway developed the concept by the theory of game of life. The outcome of the Tobler's work in the 1970s at the University of Michigan was the entrance of the CA models into the geography (Firouzabadi et al. 2009). 1990s was one of the best decades for the development of urban CA models. In the past 20 years, CA has been very useful for many researchers in the urban studies (Clarke et al. 1997; White and Engelen 1997; Wu and Webster 1998; Batty et al. 1999; Li and Yeh 2000, 2002). A regular grid of cells where each cell can be given a certain value according to its location forms CA. The changing in These values and the values of neighboring cells in a discrete time interval is accomplished according to the rules, defined in the model as the transition rules, (Wolfram 1984). Due to the bottom-up approach of this model, it is able to simulate the overall behavior of the urban growth by considering the behavior of all the urban cells which are affected by the current conditions of the central cell and the neighboring cells (Al-Kheder 2006; Feng et al. 2011). The behavior of a sophisticated system, such as an urban system, can be simulated using transition rules in the cellular automata. The probability of the conversion of a cell as a function of the driving forces of urban growth and position of all neighboring cells calculated according to Transition rules (Al-Kheder 2006; Feng et al. 2011). Spatial parameters of the transition rules have often a severe spatial correlation where the precision and accuracy of modeling can reduce. Nowadays, one of the most important research topics is the manner managing of these variables and propose solutions to minimize the effects of correlation ( $\mathrm{Li}$ and Yeh 2002; Al-Kheder 2006). So far, many articles have been published to determine the factors affecting urban growth. One of the most important articles of the article is (Wahyudi and Liu 2013) in this article Over a hundred articles published between 1993 and 2012 were selected and reviewed. The driving factors were extracted from the transition rules and classified according to their similarity and mechanism in influencing urban growth. (Table 1) they analysis shows that researches between 1993 and 2000 mainly focus on using geomorphological factors while recent studies tend to also include socio-economic factors, resulting in more sophisticated urban CA models. Nevertheless, the human-behavior factors impacting urban growth are generally under-represented (Wahyudi and Liu 2013).

In addition to this article, many other articles have also been reviewed. The results of the reviewed articles are generally presented in Table 2 . In this table, all the factors affecting urban development have been identified. 
Table 2 Factors affecting urban growth based on resources provided in table

\begin{tabular}{|c|c|c|c|}
\hline Environmental-natural & Demographic-social & Economic & Physical \\
\hline $\begin{array}{l}\text { Protected areas } \\
\text { Slope } \\
\text { Distance from faults } \\
\text { Elevation } \\
\text { Type of soil } \\
\text { Distance from river }\end{array}$ & $\begin{array}{l}\text { Population changes, population } \\
\text { density, population growth }\end{array}$ & $\begin{array}{l}\text { Price and value of land, distance } \\
\text { from the main roads, distance } \\
\text { from the city centre }\end{array}$ & $\begin{array}{l}\text { Permission to build land, limitation } \\
\text { of artificial limits, infrastructure } \\
\text { network, expansion to sensi- } \\
\text { tive and protected open spaces, } \\
\text { distances from parks and other } \\
\text { green spaces }\end{array}$ \\
\hline $\begin{array}{l}\text { Hasse (2002), Cheng and Masser } \\
\text { (2003), Al-Kheder (2006), } \\
\text { Bhatta (2010), Foroutan } \\
\text { et al. (2012), Moghadam and } \\
\text { Helbich (2013), Wahyudi and } \\
\text { Liu (2013), Mohammady et al. } \\
\text { (2014), Ahmadi and Rahmani } \\
\text { (2016), Hoseinpour et al. (2017), } \\
\text { Nowrouzifar et al. (2017) }\end{array}$ & $\begin{array}{l}\text { Cheng and Masser (2003), Al- } \\
\text { Kheder (2006), Olajoke (2007), } \\
\text { Bhatta (2010), Hoseinpour et al. } \\
\text { (2017) }\end{array}$ & $\begin{array}{l}\text { White and Engelen (1997), } \\
\text { Barnes et al. (2001), Barredo } \\
\text { et al. (2003), Cheng and Masser } \\
\text { (2003), Al-Kheder (2006), } \\
\text { Olajoke (2007), Bhatta (2010), } \\
\text { Geshkov (2010), Wahyudi and } \\
\text { Liu (2013), Deep and Saklani } \\
\text { (2014), Hoseinpour et al. (2017) }\end{array}$ & $\begin{array}{l}\text { Barnes et al. (2001), Cheng and } \\
\text { Masser (2003), Bhatta (2010), } \\
\text { Moghadam and Helbich (2013), } \\
\text { Mohammady et al. (2014), } \\
\text { Hoseinpour et al. (2017) }\end{array}$ \\
\hline
\end{tabular}

\section{Materials and methods}

\section{Urban sprawl}

Sprawl definition could be the increase in built-up and paved area with impact on loss of agricultural land, open space and ecologically sensitive habitats (Liu and Phinn 2001). The sprawl mainly causes population growth, economy and the template and preparation of infrastructure (Sudhira et al. 2003; Sudhira 2004) sprawl development is accomplished in three ways which are ribbon sprawl, leapfrog sprawl and low-density (radial) sprawl. Consumptive use of land is highly affected by provision of public infrastructures such as water, sewer, power, Telecommunication and roads. The ribbon sprawl is developed along the main transportation network that joins urban areas. The main point is that the Lands without direct access to the network remains rural or undeveloped. The leapfrog sprawl is a discontinuous pattern of urbanization in which the developed lands are widely separated from each other and it costs more than two other ways. The inherent causal and dynamics involved in the rapid changes of land-use because of urban sprawl are the most important factors, which are considered as a fit case to apply Cellular Automata models and AHP logic for simulating future scenarios (Sudhira et al. 2004).

\section{Cellular automata}

Cellular automata (CA) are a computational method, capable of simulating growth process by describing a complex system through a set of simple rules (Mantelas et al. 2008). A cellular automata model was designed for urban growth to simulate the process of urbanization in a hypothetical region. This model consists of a set of rules that describe the spatial interaction of cells and a set of parameters that lead to explore different urban forms. CA ability in the simulation
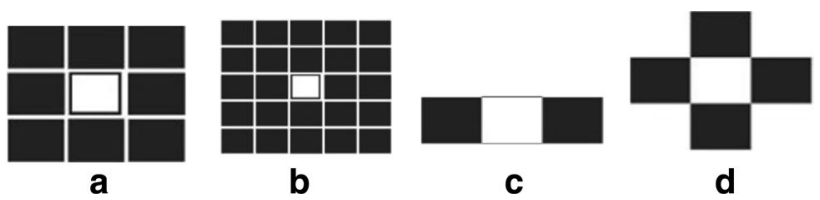

Fig. 1 a MOR's neighbourhood, b developed neighbourhood, c Van's neighbourhood in the two-dimensional CA model, $\mathbf{d}$ neighbourhood in a one-dimensional CA mode (Lee et al. 2009)

of urban growth, land use change and population expansion had become suitable for simulating complex geographical process (Feng et al. 2011). One of the best utilities of CA for geographic modeling includes its capability to support a very large parameter spaces for simulation (Torren and Benenson 2007). CA-based models behave according to the neighborhood relationships, which makes them to have dynamic and discrete systems. In the CA, space is defined as a grid, which each part of that is called cell (Moghadam and Helbich 2013) CA models including four parts: lattice, cell states, neighborhood and transition rules (Batty et al. 1999) Lattice is a grid, which is able to adopt various geometrical forms like square, hexagonal, and Trapezius shapes (Fig. 1).

CA modelling is one of the suitable ways for urban sprawl modelling (Feng et al. 2011).

Lattice: according the shape similarity to square at raster data in GIS, square shape of lattice was selected in which the size of each cell equals $10 \mathrm{~m}$ by $10 \mathrm{~m}$.

Cell state: the definition of three cell states is in the offered model, the urban state, constraint state and the nonurban state with the values of 1,0 and between 0 and 1 respectively.

Neighbourhood: the Moore neighbourhood was selected for this study.

The definition of transition rules is as follow: 
1. There is not any changing in state of the cell at simulation periods if the state of a cell is urban.

2. There is not any changing in state of the cell at simulation periods if the state of a cell is constrained.

3. Probability of a cell for transformation to the urban state will increase if affecting factors are closer to the cell.

4. The probability for transformation to urban state will increase if cells have more urban state neighbours.

5. The state of the cell will transform to urban state if calculated of a cell has the maximum value between the other cells (Mohammad et al. 2013).

\section{Analytic hierarchy process (AHP) model}

In general, it has a set of issues that are evaluated on the basis of metrics. Multiple criteria decision making (MCDM) analysis is a set of analysis methods which helps decision makers to solving complex problems with poor or incomplete structure and use their knowledge to solve these problems (Sardari and Rafieian 2008).

Analytic hierarchy process is one of the most famous multiple criteria decision making methods (Saaty 1980) which has been suggested in year time and It has been widely used in various sciences as yet (Zebardast 2001). The process consists of four steps of creating hierarchy, determining the Importance factor of the criteria and subcriteria, determine the Importance factor of the options, final rating and compatibility check in judgments (Zebardast 2001). By using this method, the appropriate weights of the affecting factors for urban growth are calculated and it is used in the production of land suitability map and formulation of transfer laws in the automated cell model

\section{Entropy model}

By using this model, we can understand the equilibrium rate of space for population clearance and the number of cities at the urban, state, regional, and country level. The whole structure of model is: In the entropy model, trending to zero, will means the increase of centralization or more centralization or unbalance in population distribution between cities, and movement toward one or higher than shows unbalance distribution in area level (Hekmatnia and Mousavi 2006). Definition of centralization degree or geographical phenomenon has been accomplished by this index (Wilson 1996).

\section{Shannon entropy model}

"Shannon entropy model is used for analysis and determination of the amount of urban disruption phenomenon" or, this indicator can be used to analyse information and the level of organization of a system (Mehrgan and Rahmani 2013). The overall structure of the model is as follow: Eq. (1) Shannon entropy formula

$\mathrm{H}=\sum_{i=1}^{n} p i^{*} \operatorname{Ln}(\mathrm{Pi})$

In the above formula:

$\mathrm{H}=$ Shannon entropy value; $\mathrm{Pi}=$ ratio of built area (total residential density) $\mathrm{i}=$ area to the total built area; $\mathrm{N}=$ total areas. The value of the entropy from zero to Ln, (n) represents a sprawl urban development. When the value of entropy is greater than in (n), urban sprawl growth has occurred (Hekmatnia and Mousavi 2006).

\section{Holdern entropy model}

Holdern is one of the basic methods for determining uneven urban growth. It is possible to determine the amount of city growth based on population growth and the amount of uneven urban growth with this method. This model first was applied to calculate the ratio population to any other source by Holdern in 1991. According to Beck et al. (2003).

In the holdern method, using the per capita formula, it is, $a=\frac{A(\text { area })}{p}$ determined how much the growth was due to population growth and how much was due to the increased per capita. Equation (2) holdern model formula

$\mathrm{A}=\mathrm{p} * \mathrm{a}$

$\mathrm{A}+\Delta \mathrm{A}=(\mathrm{p}+\Delta \mathrm{p})(\mathrm{a}+\Delta \mathrm{a})$

$\mathrm{A}+\Delta \mathrm{A}=\mathrm{pa}+\mathrm{p} \Delta \mathrm{a}+\mathrm{a} \Delta \mathrm{p}+\Delta \mathrm{p} \Delta \mathrm{a}$

$\Delta \mathrm{A}=\mathrm{p} \Delta \mathrm{a}+\mathrm{a} \Delta P \rightarrow \frac{\Delta \mathrm{A}}{\mathrm{A}}=\frac{\Delta \mathrm{a}}{\mathrm{a}}+\frac{\Delta \mathrm{p}}{\mathrm{p}}$

Note: holdern $A=\pi r^{2}$ found a general model based on population growth model Eq. (3)

$p_{t}=p_{0}\left(1+y_{p}\right)^{t}$

$p_{t}=p_{0}\left(1+g_{p}\right)^{t}$

$\ln \left(1=g_{p}\right)=\frac{1}{t} \ln \left(\frac{p_{t}}{p_{0}}\right)$

(Condition A): for the amount lesser than, $\mathrm{X}$ is equals to X. Equation (4) 
Table 3 Method for calculating the Kappa coefficient (Congalton et al. 1983; Rosenfield and Fitzpatrick-Lins 1986)

\begin{tabular}{llll}
\hline & Urban & Non-urban & Total \\
\hline Urban & $\mathrm{P} 11$ & $\mathrm{P} 12$ & $\mathrm{P} 1 \mathrm{~T}=(\mathrm{P} 11+\mathrm{P} 12)$ \\
Non-urban & $\mathrm{P} 21$ & $\mathrm{P} 22$ & $\mathrm{P} 2 \mathrm{~T}=(\mathrm{P} 21+\mathrm{P} 22)$ \\
Total & $\mathrm{PT} 1=\mathrm{P} 11+\mathrm{P} 21)$ & $\mathrm{PT} 2=(\mathrm{P} 12+\mathrm{P} 22)$ & $(\mathrm{P} 1 \mathrm{~T}+\mathrm{P} 2 \mathrm{~T}+\mathrm{PT} 1+\mathrm{PT} 2)$ \\
\hline
\end{tabular}

$g_{p}=\frac{1}{t} \ln \left(\frac{p_{t}}{p_{0}}\right)$

$g_{a}=\frac{1}{t} \ln \left(\frac{a_{t}}{a_{0}}\right) \quad \rightarrow g_{A}=g_{p}+g_{a}$

$g_{A}=\frac{1}{t} \ln \left(\frac{A_{t}}{A_{0}}\right) \quad \ln \left(\frac{A_{t}}{A_{o}}\right)=\ln \left(\frac{p_{t}}{p_{o}}\right)+\left(\frac{a_{t}}{a_{o}}\right)$

\section{Kappa coefficient analysis}

\section{Calculating the kappa coefficient}

The Kappa coefficient and the overall accuracy are used to assess the proposed model. For this purpose, error matrix is computed as shown in Table 3 (Monserud and Leemans 1992; Pontius 2001).

Kappa is declared to have two advantages over raw accuracy:

- Kappa considers all the cells of an error matrix and thus incorporates more information (Rosenfield and Fitzpatrick-Lins 1986; Fung and LeDrew 1988; Dicks and Lo 1990; Janssen and Vanderwel 1994);

- Kappa is suitable for comparison between different error matrices because it removes chance agreement (Congalton et al. 1983; Congalton 1991).

Congalton et al. (1983) proposed an application of the Kappa analysis, (as described by Cohen 1960; Bishop et al. 1989), as a means of improving the interpretation of the error matrix. Kappa analysis yields a $\mathrm{K}_{\text {hat }}$ coefficient that measures the difference between the observed agreement of the two maps and the agreement that might be attained by chance matching (Hurley et al. 1997). The $\mathrm{K}_{\text {hat }}$ coefficient is computed as follows: Eq. (5)

$K($ hat $)=\frac{P(A)-P(E)}{1-P(E)}=\frac{\sum_{i=1}^{C} \text { Pii }-\sum_{i=1}^{c} \text { PiT PTi }}{1-\sum_{i=1}^{c} \text { PiT PTi }}$

$\mathrm{C}$ : is the number of categories in the error matrix $\mathrm{P}_{\mathrm{ii}}$ is the number of cells in row $\mathrm{i}$ and column $\mathrm{i}$

$\mathrm{P}_{\mathrm{IT}}$ is the total number of cells in row $\mathrm{i}$ (shown as the row total in the matrix)
$\mathrm{P}_{\mathrm{TI}}$ is the total number of cells in column $\mathrm{i}$ (shown as the column total in the matrix)

Where $\mathrm{P}_{\mathrm{a}}$ is the percent correct for model output, and $\mathrm{P}_{\mathrm{E}}$ is the expected percent correct due merely to chance.

\section{Research methodology}

The research method of this article is practical which its theoretical bases are collected by documentary method and quantitative and comparative methods have been used for its analysis. In this study, first, the automated cell model is checked and then the effective factors on urban growth are determined by using resource review and aerial photography of the study area at different time intervals. Subsequently, analytical maps related to the effective factors on urban growth in GIS software are produced and the weights obtained through the hierarchical analysis process of comparing the development stimuli relative to each other in the applied layers and overlapping the different layers and Considering the limitations of developing land suitability map as inputs for the automated cell model is produced. Finally, the model is conceptually designed and integrated with the hierarchical analysis process which using the model definition of the automated cell model. Then the conceptual model has been converted into software codes and used to predict city growth in the surrounding lands.

\section{Recognition of the studied area}

Qazvin is the city canter and it is Qazvin province. Qazvin is located 50-north longitude and 36.15 east latitude of the Greenwich meridian. The area of the city is 3701 hectares. At present, Qazvin has three regions areas, with the total population of the three regions equal to 450 thousand (Fig. 2).

\section{Data and preparation of them}

The data used in this research are satellite images of Landsat Qazvin. Figures 3 and 4 show Landsat images in 1996 and 2016. The Specifications of satellite images related to the city of Qazvin are shown in Tables 4, 5. 
Fig. 2 Location of Qazvin city in province, county and country
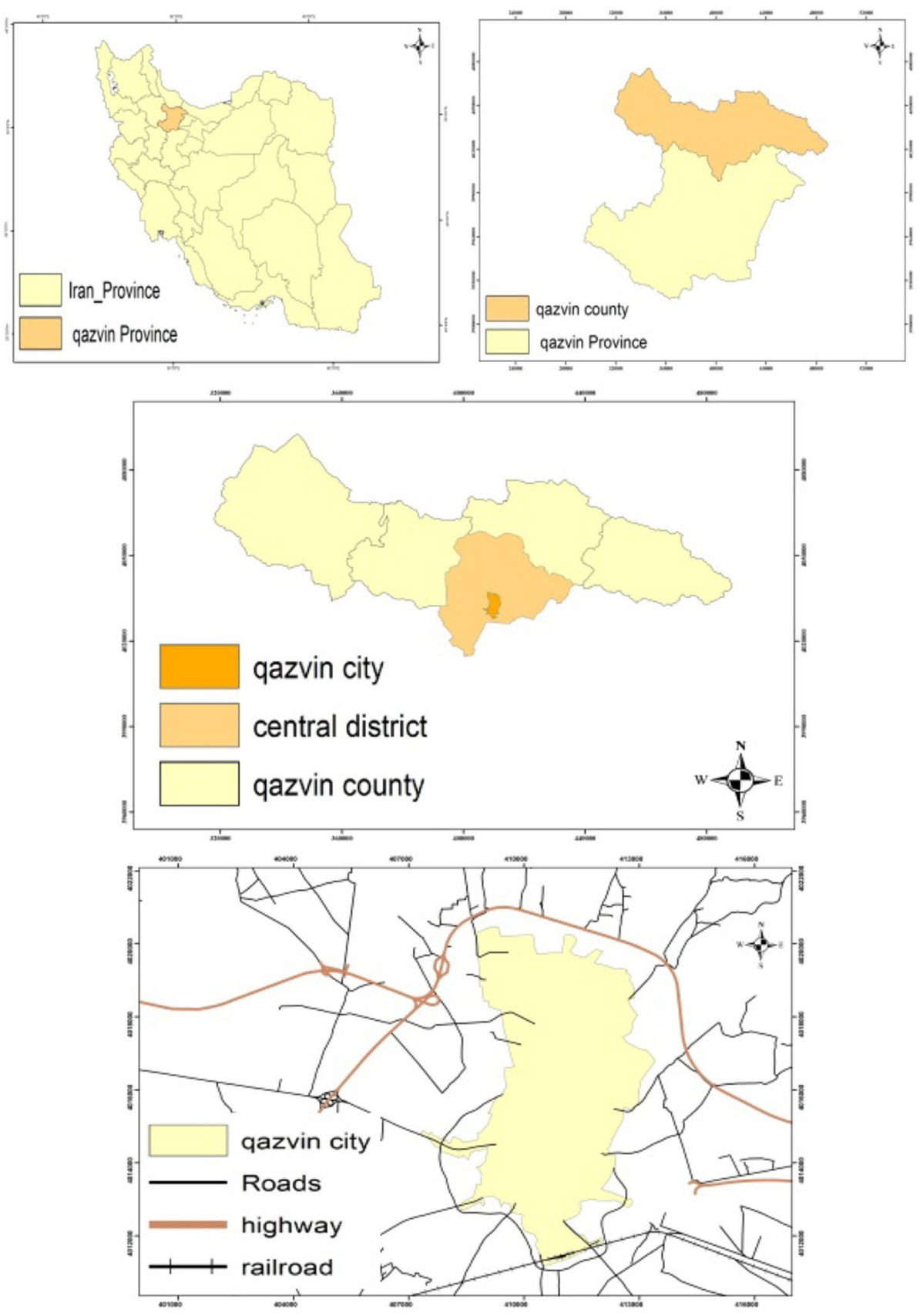

\section{Sprawl study in Qazvin city}

\section{Entropy model}

Investigation of urban sprawl growth in Qazvin using the holdern model (for the years 1956-2016)

The result of this investigation is in Tables $6,7,8$.

According to the result of two Shannon and Holdern Modern, it is observed that Qazvin has grown physically increasingly due to over concentration on population and activity.
Findings from the studying of Qazvin's documents and reports, natural and artificial factors affecting the physical development of Qazvin

The results of reviewing the documents and reports on the Factors and obstacles of physical expansion in Qazvin are presented in Table 9. Location, studies factors in Qazvin city. 


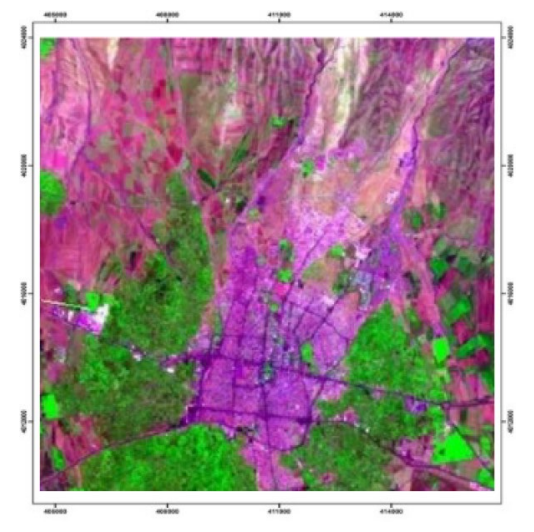

Fig. 3 Image of Landsat Qazvin 1996

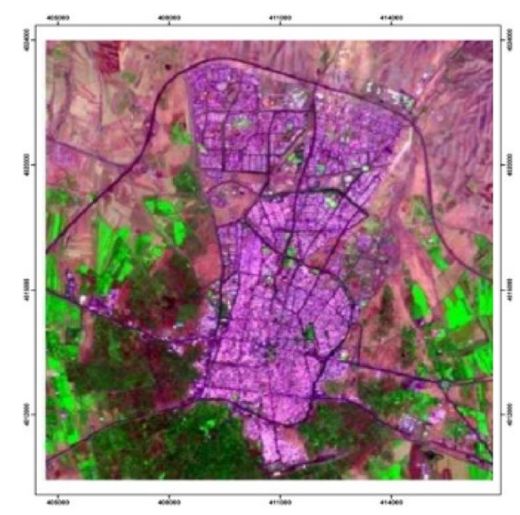

Fig. 4 Image of Landsat Qazvin_2016

\section{Studies factors in Qazvin city}

Allow construction, and vision and perspective.

Distance from the river, distance from fault, contour line, type of soil, accessibility to urban roads and land prices.

At the beginning of the simulation, urban growth has been done for the year 2016. After the prediction of urban growth by 2016 and comparing it with the current situation's map of that year, it can be concluded that the urban simulation (for 2016) has a high overlap with the aerial map

Table 4 Specifications satellite images of Qazvin city (http://glovi s.usgs.gov)

\begin{tabular}{llll}
\hline Satellite & Sensor type & Spatial resolution & Base- level \\
\hline Terra & ASTER & 30 & WGS84 \\
\hline
\end{tabular}

of that year. In addition, in order to check the accuracy of the model, the Kappa coefficient is used, and the results of that are illustrated in Table 10. Regarding this issue that the value of the Kappa coefficient is $92.3 \%$, it can be stated that the performed simulation is correct for 2016. In the next step, Fig. 5 is used to simulate urban growth by 2026, and the results of the final simulation are shown in figure.

\section{Results of kappa}

The quantitative results of the model are illustrated Table 10 .

\section{How to implement AHP and cellular automate models in Qazvin}

First step: At this step, first, layers associated with the effective factors on urban growth are prepared and after repackaging each layer, the weights calculated by the hierarchical analysis process are applied to the layers and overlapped. At this step, the probability of each cell's status being transformed into a cell-dependent status is rely on the effective factors on urban growth and the effect of each factor on the weight of each cell is considered as weight shape.

This probability is calculated by the following relation where $\mathrm{P}_{\mathrm{AHF}}$ is Probability of cell change indicates the ' in this equation $s_{n}$ is equaled to $w_{1} \times s_{1}+w_{2} \times s_{2}+\cdots+w_{n} \times s_{n}$ and $\sum_{1}^{n} w_{n} s_{n}$ growth factor is the "value of the class in which the intended cell is growth to the growth factors and $w_{n}$.

Weight of Eq. (6)

$p_{a h f}=1-\frac{1}{\sum_{1}^{n} w_{n} \times s_{n}}$

Second step: At this step, according to the components, the automated cells are divided into four main parts, the cell, the cell status, the neighborhood, the transfer rules and the sub-part of time and at this step the automated cell model is defined as its components.

Third step: This will be calculated by checking the population and the number of cells which built in previous years. Because of using of this limiting factor, this type of automated cells is called as auto-restricted cells.

Fourth step: In the combination part, first determine the cell type and status and accordingly all the calculations which performed in the first and third steps will combine by using the following equation and then calculate with the
Table 5 Specifications DEM Qazvin city (Source: http://glovi s.usgs.gov)

\begin{tabular}{llllll}
\hline Imaging date & Type of satellite & Sensor type & $\begin{array}{l}\text { Spatial } \\
\text { resolution }\end{array}$ & Base-level & Image system \\
\hline 1996-11-27 & Landsat & ETM & 30 & WGS84 & UTM, Zone 39 N \\
$2016-08-07$ & Landsat & ETM & 28.5 & WGS84 & UTM, Zone 39 N \\
\hline
\end{tabular}


Table 6 Calculation of Shannon entropy for the year 1996 in Qazvin (Source: Calculations of Writers)

\begin{tabular}{lclll}
\hline Region & $\begin{array}{l}\text { The built area } \\
\text { (hectare) }\end{array}$ & $\mathrm{Pi}$ & $(\mathrm{Ln}) \mathrm{Pi}$ & $\mathrm{Pi}$ Ln(Pi) \\
\hline 1 & 587 & 0.4054 & 0.9028 & 0.3660 \\
2 & 716 & 0.4954 & 0.7024 & 0.3480 \\
3 & 145 & 0.1001 & 2.3016 & 0.2303 \\
Total & 1448 & $\sum P i=1$ & $\sum P i * \operatorname{Ln}(P i)$ & 0.9443 \\
\hline
\end{tabular}

Table 7 Calculation of Shannon entropy for the year 2016 in Qazvin (Source: Calculations of Writers)

\begin{tabular}{lclll}
\hline Region & $\begin{array}{l}\text { The built area } \\
\text { (hectare) }\end{array}$ & $\mathrm{Pi}$ & $(\mathrm{Ln}) \mathrm{Pi}$ & $\mathrm{Pi}{ }^{*} \operatorname{Ln}(\mathrm{Pi})$ \\
\hline 1 & 1328 & 0.3204 & 1.1382 & 0.3647 \\
2 & 1136 & 0.4040 & 0.9063 & 0.3661 \\
3 & 933 & 0.2756 & 1.2888 & 0.3551 \\
Total & 2297 & $\sum P i=1$ & $\sum P i * \operatorname{Ln}(P i)$ & 1.0859 \\
\hline
\end{tabular}

conversion rate and enter to the model and computer program as a control factor.

$\mathrm{P}_{\text {total }}=\mathrm{P}_{\mathrm{AHP}} \times \Omega$

\section{Data preparation}

In order to calculate the weights and degree of importance of the effective factors on urban growth, a hierarchical analysis process has been used in this study. At first, the matrix of pairwise comparisons of factors to criteria and criteria to each other is formed and criteria scoring to each other and factors to criteria is performed using expert in Delphi technique and using the field of view. For calculating the weight of each factor, the Expert choice software has been used in hierarchical analysis process method. The results are implemented on analytical maps of the effective factors on urban growth (Figs. 6, 7).

Then, after calculating the weight of each of the effective factors in urban growth, using the hierarchical process and preparation of layers associated with the factors of growth of layers' overlap by applying the weight of each layer. Then

Table 10 The quantitative results of Kappa (Source: Calculations of Writers)

\begin{tabular}{lllr}
\hline 2016 & 1996 & & \\
\cline { 2 - 4 } & Urban & Non-urban & Total 1996 \\
\hline Urban & 1920.81 & 0 & 1920.81 \\
Non-urban & 1781.14 & 6358.39 & 8139.53 \\
Total 2016 & 3701.95 & 6358.39 & 10060.34 \\
\hline
\end{tabular}

Table 8 The investigation of sprawl growth of Qazvin using Holdern model (Source: Calculations of Writers)

\begin{tabular}{lll}
\hline Years 1996-2016 & Years 1976-1996 & Years 1956-1976 \\
\hline $\mathrm{r}=1.52+(-0.52)$ & $\mathrm{r}=0.511+0.49$ & Due to population growth \\
100\% due to population growth & 49\% due to per capita growth & \\
0\% due to per capita growth & 51\% due to population growth & \\
\hline
\end{tabular}

Table 9 Obstacles, directions and reasons for lack of physical development in Qazvin (Source: Calculations of Writers)

\begin{tabular}{|c|c|c|c|}
\hline Reasons & Directions & Obstacles & Factors \\
\hline $\begin{array}{l}\text { High elevation of the area between } 1700 \text { and } 2400 \mathrm{~m} \\
\text { Lack of soil formation } \\
\text { High slope of the region so as the } 60^{\circ} \text { slope is observed }\end{array}$ & North & Altitudes & Natural \\
\hline $\begin{array}{l}\text { Food value } \\
\text { Economic development of area } \\
\text { Groundwater penetration and nutrition of its aquifers } \\
\text { Problems of infrastructures due to the alluvial nature of the land } \\
\text { Having Privacy }\end{array}$ & South, East, West & Agricultural lands & \\
\hline $\begin{array}{l}\text { Employment } \\
\text { Economic development of the region } \\
\text { Environmental pollution } \\
\text { Finding Proper location in terms of climate }\end{array}$ & Southeast & Industrial towns & Man-made \\
\hline $\begin{array}{l}\text { Lack of land } \\
\text { Appropriate location } \\
\text { Appropriate distance from the city } \\
\text { Dependent use }\end{array}$ & Southeast & Cemetery & \\
\hline $\begin{array}{l}\text { Very large area } \\
\text { Military significance }\end{array}$ & Different parts of city & Garrisons & \\
\hline
\end{tabular}



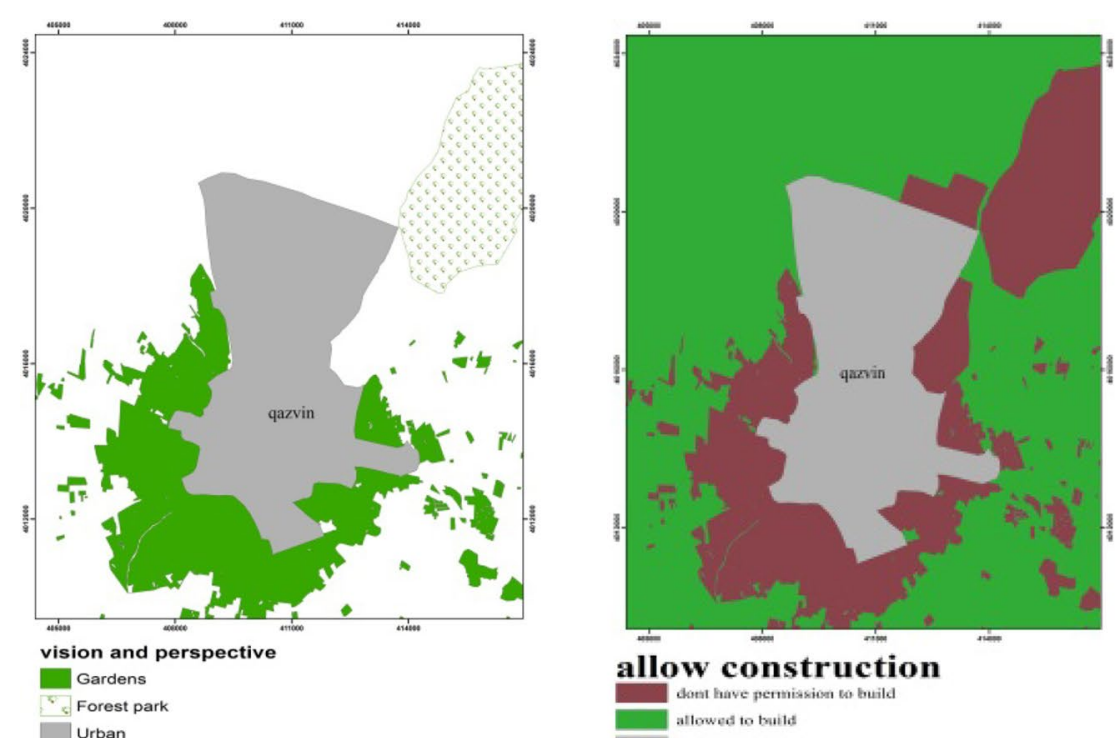

\section{allow construction \\ allow consersiasien to tuild}

allowed to baild

Urban
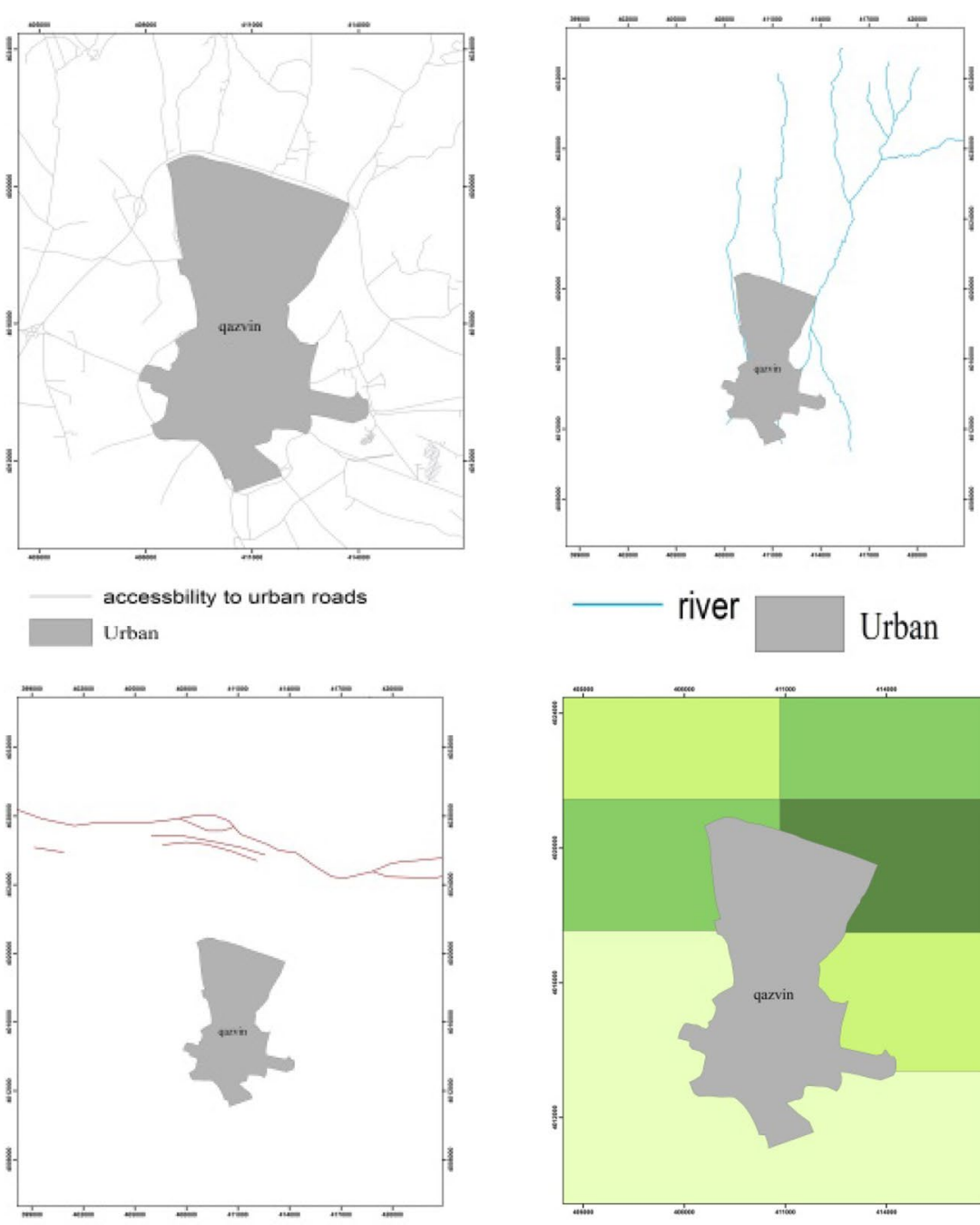

fault

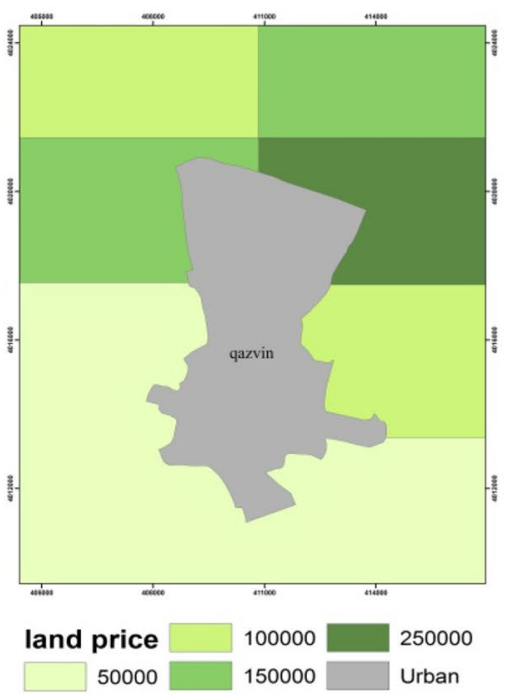

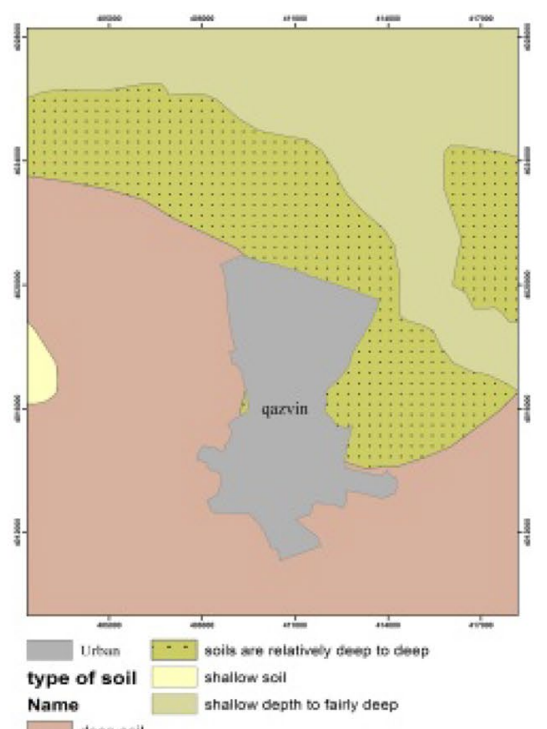

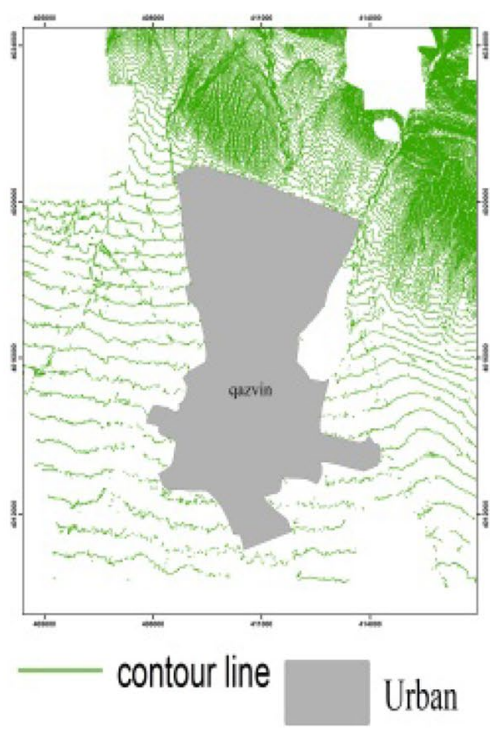

(Fig 6), Location, studies factors in Qazvin city

Fig. 5 Location, studies factors in Qazvin city 


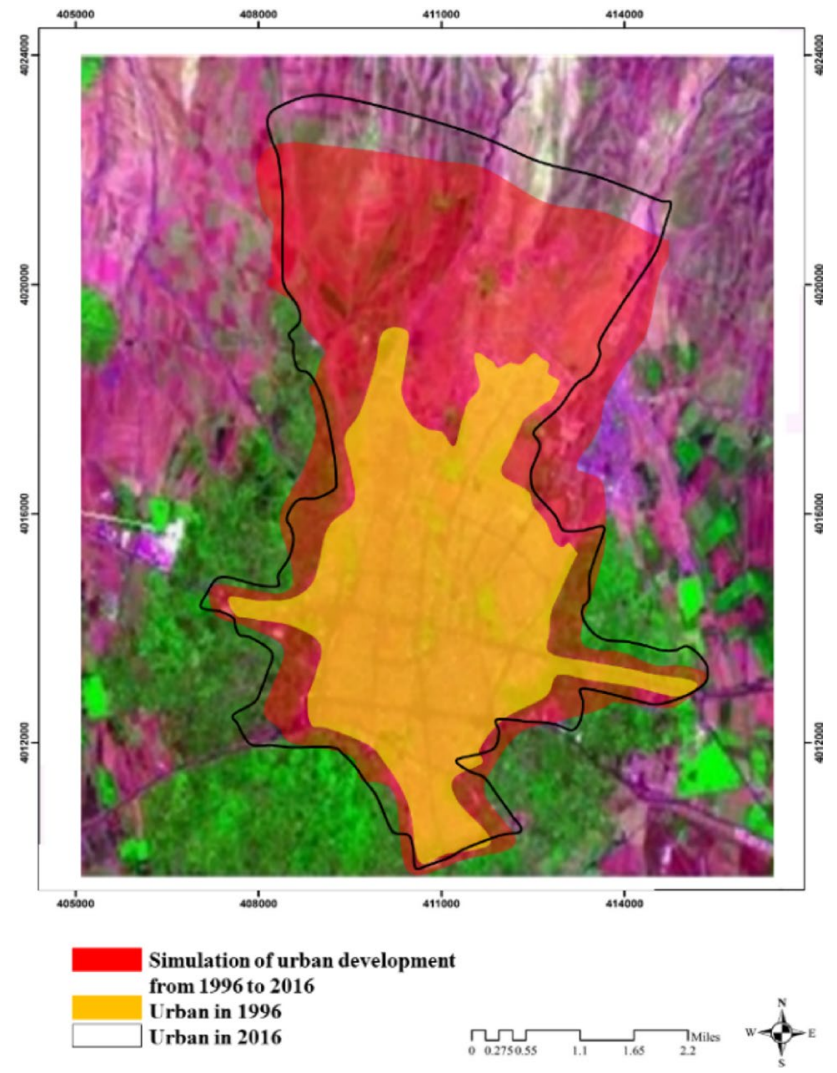

Fig. 6 Final simulation in Qazvin city

the weighted probability of transforming the cell status is calculated. The results are prepared in the form of land suitability map and as input to the model. In order to calculate the land conversion rate, population and cell number of the state constructed in different periods, the correlation coefficient value was calculated by deviating from the mean for two population variables and the number of land pixels constructed.

In order to calculate the land conversion rate, population and cell number, the status has been determining at different time periods and then the Pearson correlation coefficient has been calculated by the way of deviating from the mean for the two population variables $\mathrm{X}$ and the number of land pixels $Y$ calculated. The calculated value of Pearson's correlation coefficient was 8.83 which indicating a strong correlation between the two variables. After determining the existence of a direct and strong correlation between the two variables $\mathrm{x}$ and $\mathrm{y}$, linear Regression method has been used to predict the number of convertible pixels in different time periods and predicted year.

At the end, the model becomes software codes. Due to the high volume of data and computations in the model designed according to the time and data flow in the model, the formulas and the model work, the computer has been used to implement it. In order to implement the model in the computer, each supply step and model components are separately converted into software codes and then linked together for initial testing and final output. The computer codes of this program are written in MATLAB programming language.

Then the validation and model results are performed. In order to evaluate the validity of the designed model, first the land growth map in 2016 is modeled by using data available in 1996 and to evaluate the degree of agreement of a model with reality, the Kappa coefficient reality, visual matching overlap and observation are used. The calculated kappa coefficient is 0.95 .

This value represents a $92 \%$ compliance with the modeled reality map which is based on the provided standard by the United States Geological Survey institute that considers the minimum acceptable value for the Kappa coefficient to be $85 \%$. It can be said that the designed model has sufficient reliability and validity to modeling the urban growth in the surrounding lands. According to the acceptable results of the model, it has been used to predict the urban growth in the surrounding lands. Then, all the happened steps in the data of 2016 are implemented as input data and the growth simulation of Qazvin city up to 2026 is performed which the results are presented in map 10.

\section{Conclusion}

Nowadays, cities are experiencing rapid urban growth that destroys farmland, the formation of private housing, and the irregular expansion of the city. Expanding cities always changes the use of different lands to urban use. Due to the inevitable changes, awareness of this trend is important for its guidance towards the desired direction. Therefore, there is a fundamental need to realistically predict cities growth in the future, to determine the impact of various planning scenarios on the urban growth process and to answer the questions ((what if) any) questions. Due to the inevitable changes, awareness of this trend is important for its guidance towards the desired direction. For this reason, so far, many models have been created and used to simulate the development of the city and to expand the use of urban lands. In this research, the automated cellular model.

This model uses a suitable method for searching and selecting land for development. The implemented model was applied using data for 2016 to predict the development of 2026 year.

One of the characteristics of this model is its implementation on a wide area with a regional scale. The results of this research revealed that although urban development is really difficult to predict, but with the proper selection of the most important factors affecting it and the use of a model that has 


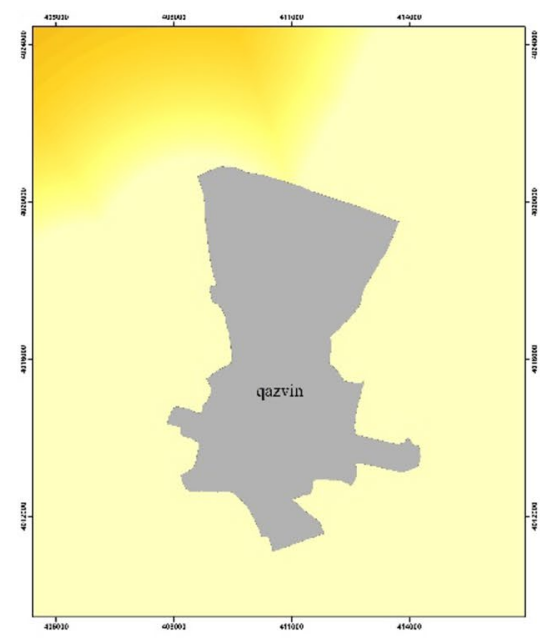

fuccy-vision and perspective Value
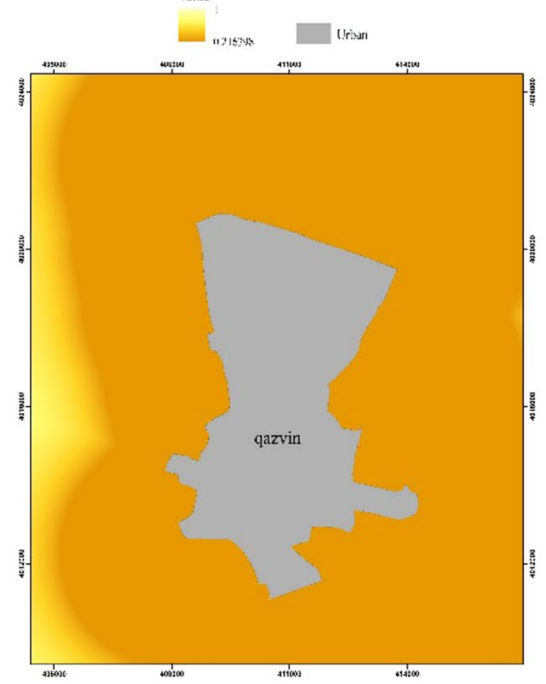

fuzzy-distance from the river

Value
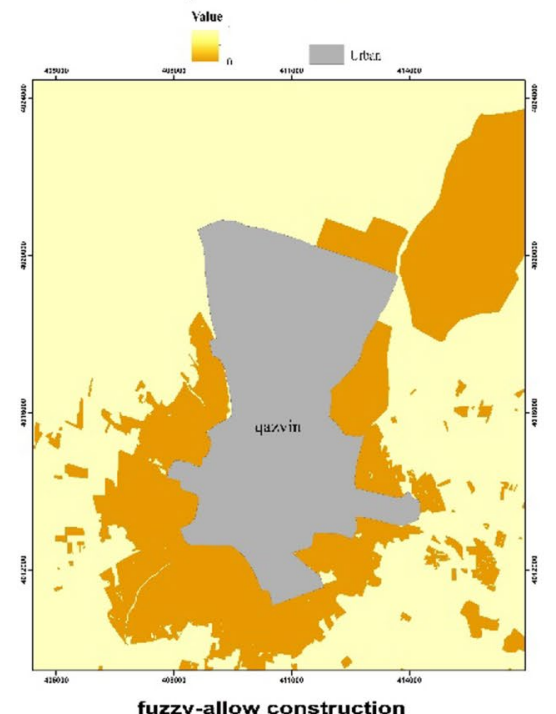

valne
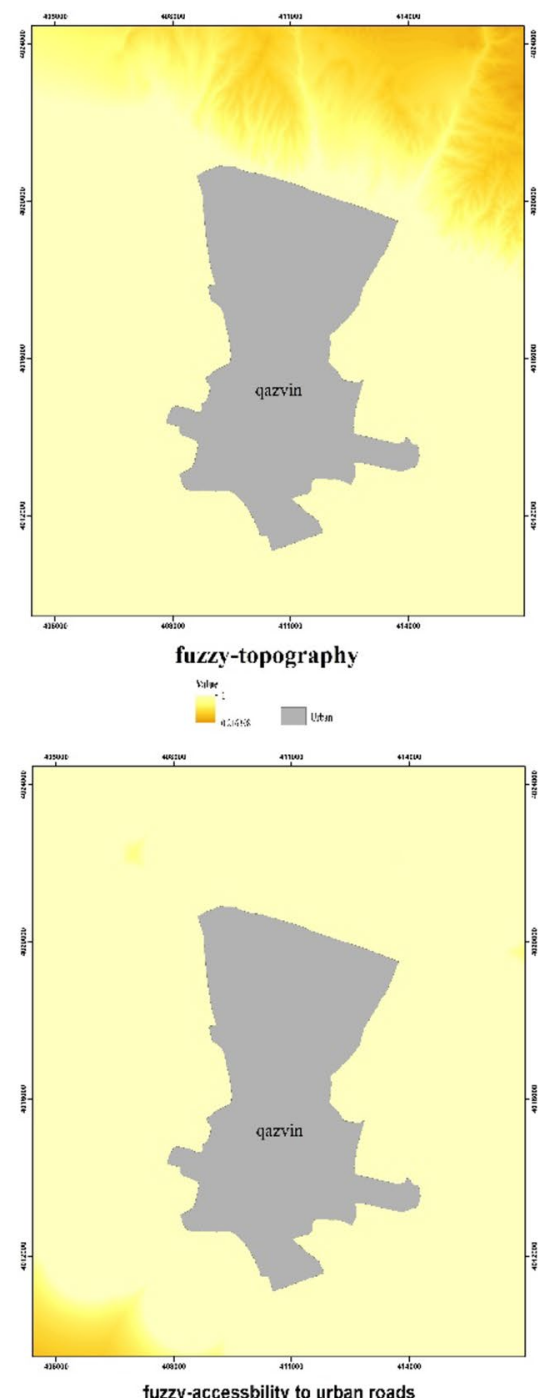

fuzzy-accessbility to urban roads

$$
\text { value , }
$$

${ }_{i}^{1} \square$ เrxo

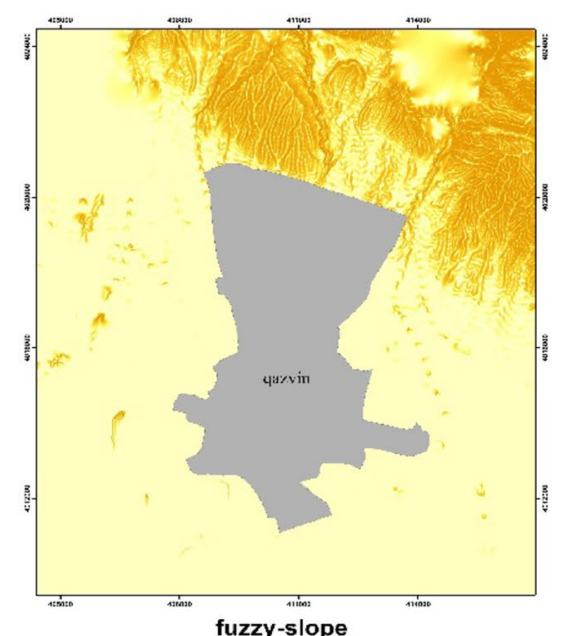

value
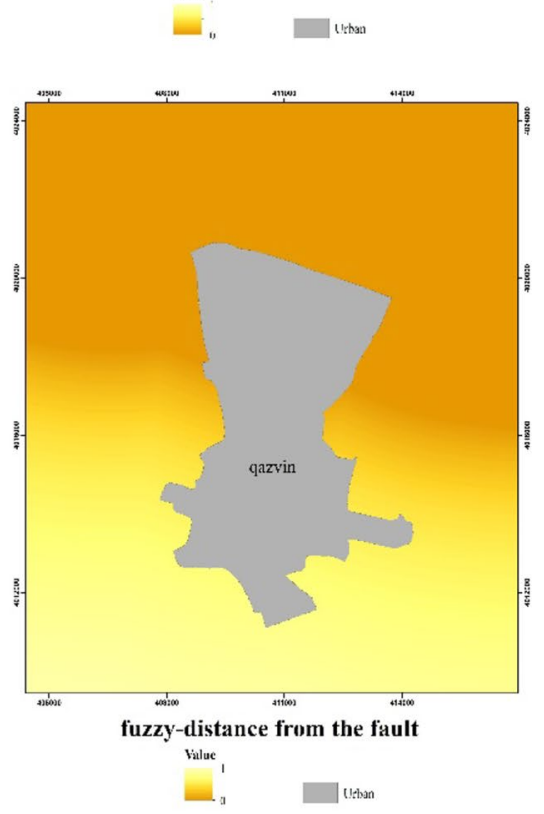

Fig. 7 Fuzzy maps provided by the criteria for effective physical development of Qazvin 


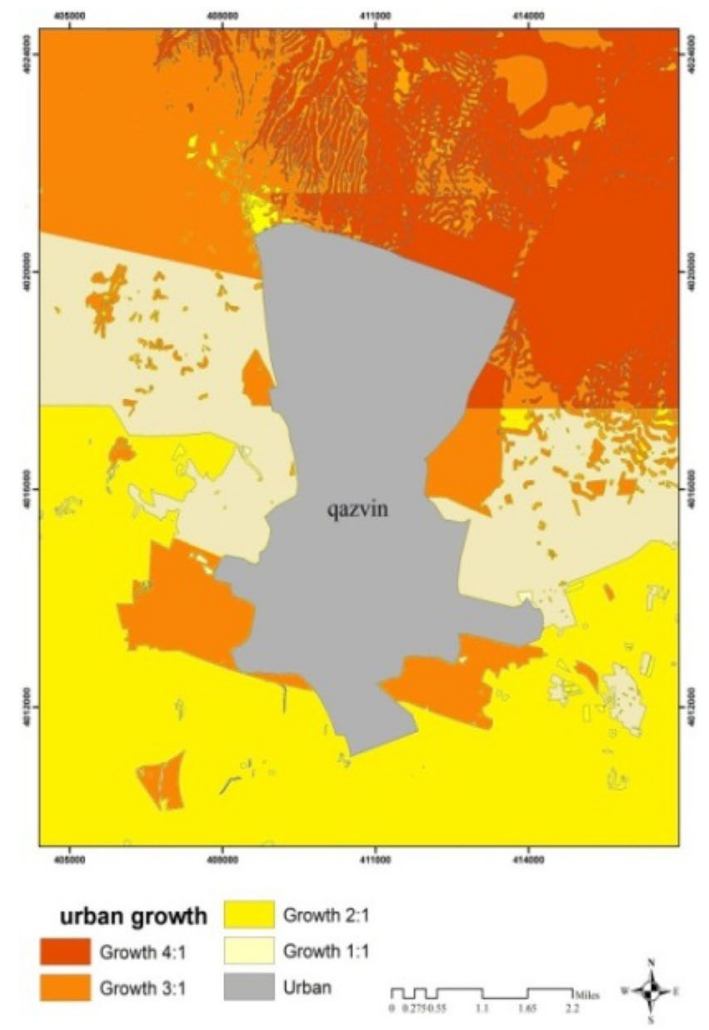

Fig. 8 Proposed map of Qazvin city development

high adaptability to the conditions, which it can be more possible to predict the future development and took steps in order to a better management and directing them. Also, this research showed that cellular automate model as a low to high level model can simulate many human decision-making behaviours properly and by obtaining results, shows the general trend of social phenomena such as land use development. In addition, GIS has proven its capabilities as a suitable way to preparing factors, modelling their behaviour and analysing the results from their activities. The model developed in this study is very flexible due to its numerous and effective parameters for adaptation to the environment. Due to its favourable results, it can be used in other areas as well. Finally, the future of urban development was predicted by using the AHP model and automatic cells in the GIS environment. As can be seen in the (Fig. 8), the optimal growth of Qazvin city is projected in the East and West directions. The results of the research help a lot of planners and urban decision makers to understand the perspectives of sustainable urban development.

Open Access This article is distributed under the terms of the Creative Commons Attribution 4.0 International License (http://creat ivecommons.org/licenses/by/4.0/), which permits unrestricted use,

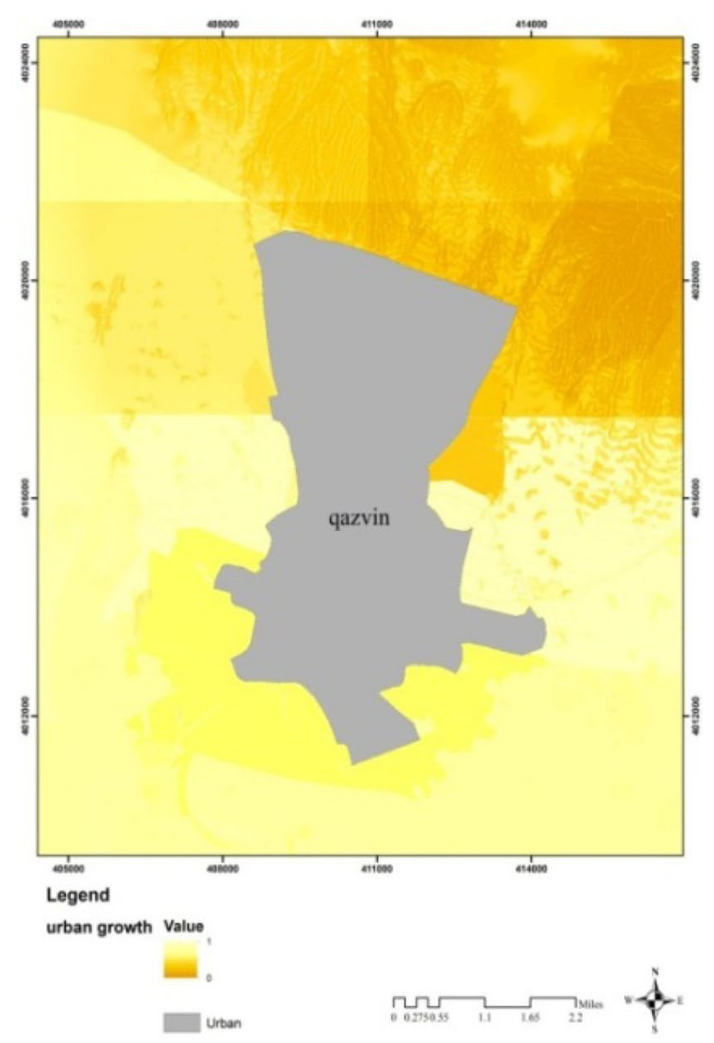

distribution, and reproduction in any medium, provided you give appropriate credit to the original author(s) and the source, provide a link to the Creative Commons license, and indicate if changes were made.

\section{References}

Ahmadi M, Rahmani M (2016) Seismic hazard zoning of Hamadan Town for urban development by using remote sensing and GIS. Int J Humanit Cult Stud (IJHCS) ISSN 2356-5926 983-999

Al-Kheder SA (2006) Urban growth modeling with artificial intelligence techniques. Purdue University, West Lafayette

Barnes KB et al (2001) Sprawl development: its patterns, consequences, and measurement. Towson University, Towson, pp 1-24

Barredo JI et al (2003) Modelling dynamic spatial processes: simulation of urban future scenarios through cellular automata. Landsc Urban Plan 64(3):145-160

Barreira-González P et al (2015) From raster to vector cellular automata models: a new approach to simulate urban growth with the help of graph theory. Comput Environ Urban Syst 54:119-131

Batty M et al (1999) Modeling urban dynamics through GIS-based cellular automata. Comput Environ Urban Syst 23(3):205-233

Beck R et al (2003) Outsmarting smart growth. Center for Immigration Studies, Washington DC

Bhatta B (2010) Analysis of urban growth and sprawl from remote sensing data. Springer Science \& Business Media, Berlin

Bishop YM et al (1989) Holland (1975) Discrete multivariate analysis: theory and practice. MIT Press, Cambridge 
Bone C et al (2006) A AHP-constrained cellular automata model of forest insect infestations. Ecol Model 192(1-2):107-125

Cheng J, Masser I (2003) Urban growth pattern modeling: a case study of Wuhan city, PR China. Landsc Urban Plan 62(4):199-217

Chu YW, Tang JT (2005) The Internet and civil society: environmental and labour organizations in Hong Kong. Int J Urban Reg Res 29(4):849-866

Clarke KC et al (1997) A self-modifying cellular automaton model of historical urbanization in the San Francisco Bay area. Environ Plan B Plan Des 24(2):247-261

Cohen J (1960) A coefficient of agreement for nominal scales. Educ Psychol Meas 20(1):37-46

Congalton RG (1991) A review of assessing the accuracy of classifications of remotely sensed data. Remote Sens Environ 37(1):35-46

Congalton RG et al (1983) Assessing landsat classification accuracy using discrete multivariate analysis statistical techniques. Photogramm Eng Remote Sens 49(12):1671-1678

Deep S, Saklani A (2014) Urban sprawl modeling using cellular automata. Egypt J Remote Sens Space Sci 17(2):179-187

Dicks SE, Lo TH (1990) Evaluation of thematic map accuracy in a land-use and land-cover mapping program. Photogramm Eng Remote Sens (USA) ISSN 0099-1112

Firouzabadi ZP, Shakiba A, Matkan A, Sadeghi A (2009) Remote sensing (RS), geographic information system (GIS) and cellular automata model (CA) as tools for the simulation of urban land use change - a case study of Shahr-e-Kord. Environ Sci 7(1)

Feng $\mathrm{Y}$ et al (2011) Modeling dynamic urban growth using cellular automata and particle swarm optimization rules. Landsc Urban Plan 102(3):188-196

Foroutan E et al (2012) Integration of genetic algorithms and AHP logic for urban growth modelling. ISPRS Ann Photogramm Remote Sens Spat Inf Sci 1:69-74

Fung T, LeDrew E (1988) For change detection using various accuracy. Photogramm Eng Remote Sens 54(10):1449-1454

Geshkov MV (2010) The effect of land-use controls on urban sprawl. $\mathrm{Ph} . \mathrm{D}$. Thesis, the University of South Florida

Greenhalgh P, Gudgeon C (2004) Mechanisms of urban change: regeneration companies or development corporations? North Econ Rev 35:53-72

Hasse JE (2002) Geospatial indices of urban sprawl in New Jersey. Rutgers University, New Brunswick

$\mathrm{He} \mathrm{Y}$ et al (2015) Deriving urban dynamic evolution rules from selfadaptive cellular automata with multi-temporal remote sensing images. Int J Appl Earth Obs Geoinf 38:164-174

Hekmatnia H, Mousavi M (2006) The application of model in geography with the emphasis on urban and regional planning. Elm-eNovin publications, Yazd

Hoseinpour $\mathrm{H}$ et al (2017) Investigating urban expansion and its drivers in Ardebil. Int J Archit Urban Dev 7(4):19-26

Hurley A (1997) Fiasco at wagner electric: environmental justice andurban geography in St. Louis. Environ Hist 2:460-481

Janssen LL, Vanderwel FJ (1994) Accuracy assessment of satellite derived land-cover data: a review. Photogramm Eng Remote Sens (United States) 60(4):419-426

Junfeng J (2003) Transition rule elicitation for urban cellular automata models, case study. wuhan, China (Thesis submitted to the international institute for geo-information science and earth observation in partial fulfilment of the requirement's for degree of master of science in geo-information science and earth observation with specialization in urban planning and management)

Lee ST, Lei TC, Lu CW (2009) Artificial neural network and cellular automata as a modeling simulation for night market spatial development. Korea Society of Design Sience, Seoul, pp 507-516
Li X, Yeh AG-O (2000) Modelling sustainable urban development by the integration of constrained cellular automata and GIS. Int J Geogr Inf Sci 14(2):131-152

Li X, Yeh AG-O (2002) Neural-network-based cellular automata for simulating multiple land use changes using GIS. Int J Geogr Inf Sci 16(4):323-343

Liu Y, Phinn SR (2001) Developing a cellular automaton model of urban growth incorporating fuzzy set approaches. Int J Comput Environ Urban Syst 27:637-658

Mantelas L, Prastacos P, Hatzichristos T (2008) Modeling urban growth using fuzzy cellular automata. In: 11th AGILE international conference on geographic information science. University of Girona, Spain

Mehrgan M, Rahmani B (2013) Cities dealing with space structure analysis of Lorestan State (Iran) using entropy model at urban, province, township, district and national levels. J Geogr Reg Plan 6(1):1-9

Moghadam HS, Helbich M (2013) Spatiotemporal urbanization processes in the megacity of Mumbai, India: a Markov chains-cellular automata urban growth model. Appl Geogr 40:140-149

Mohammad M et al (2013) Urban growth simulation through cellular automata (CA), analytic hierarchy process (AHP) and GIS; case study of 8th and 12th municipal districts of Isfahan. Geogr Tech 8:57-70

Mohammady S et al (2014) Urban growth modeling using AN artificial neural network a case study of Sanandaj City, Iran. Int Arch Photogramm Remote Sens Spat Inf Sci 40(2):203

Monserud RA, Leemans R (1992) Comparing global vegetation maps with the Kappa statistic. Ecol Model 62(4):275-293

Natale ES et al (2015) Assessment of the conservation status of natural and semi-natural patches associated with urban areas through habitat suitability indices. Int J Environ Res 9(2):495-504

Nowrouzifar A et al (2017) Urban growth modeling using integrated cellular automata and gravitational search algorithm (case study: Shiraz city, Iran). J Geomat Sci Technol 7(1):29-39

Olajoke A (2007) The pattern, direction and factors responsible for urban growth in a developing African city: a case study of Ogbomoso. J Hum Ecol 22(3):221-226

Pontius R (2001) Quantification error versus location error in comparison of categorical maps (vol 66, pg 1011, 2000). Photogramm Eng Remote Sens 67(5):540

Qiu-Hao H, Yun-Long C (2006) Assessment of karst rocky desertification using the radial basis function network model and GIS technique: a case study of Guizhou Province, China. Environ Geol 49(8): 1173-1179

Rosenfield GH, Fitzpatrick-Lins K (1986) A coefficient of agreement as a measure of thematic classification accuracy. Photogramm Eng Remote Sens 52(2):223-227

Saaty TL (1980) The analytic hierarchy process: planning, priority setting,resource allocation. McGraw-Hill International Book Co., New York; London (ISBN:0070543712 9780070543713)

Sardari M, Rafieian M (2008) Modeling the growth of informal settlements with emphasis on support systems, modeling the growth of informal settlements with emphasis on support systems

Sudhira $\mathrm{H}$ et al (2003) Urban sprawl pattern recognition and modeling using GIS. Proc Map India-2003, New Delhi

Sudhira HS (2004) Integration of agent-based and cellular automata models for simulating urban sprawl (thesis submitted to the international institute for geo - information science and earth observation in partial fulfilment of the requirements for the degree of master of science in geo - informations. December 2004)

Sudhira H et al (2004) Urban sprawl: metrics, dynamics and modelling using GIS. Int J Appl Earth Obs Geoinf 5(1):29-39

Torren PM, Benenson I (2007) Geographic automata systems. Geogr Inf Sci 19(4):385-412 
Wahyudi A, Liu Y (2013) Cellular automata for urban growth modeling: a chronological review on factors in transition rules. In: A presentation for the 13th edition of the International Conference on Computers in Urban Planning and Urban Management (CUPUM) takes place in the Faculty of Geosciences of Utrecht University on 2-5 July 2013 at the Uithof Campus in Utrecht, NL

White R, Engelen G (1997) Cellular automata as the basis of integrated dynamic regional modelling. Environ Plan B Plan Des 24(2):235-246

Wilson MA (1996) The socialization of architectural preference. J Environ Psychol 16(1):33-44

Wolfram S (1984) Cellular automata as models of complexity. Nature 311(5985):419
Wu F, Webster CJ (1998) Simulation of natural land use zoning under free-market and incremental development control regimes. Comput Environ Urban Syst 22(3):241-256

Yang Q et al (2013) Incorporating geographical factors with artificial neural networks to predict reference values of erythrocyte sedimentation rate. Int J Health Geogr 12(1):11

Zebardast A (2001) Applying hierarchical analytical process in urban and regional planning. Fine Arts 10(2):13-21

Publisher's Note Springer Nature remains neutral with regard to jurisdictional claims in published maps and institutional affiliations. 